\title{
Prevalence of goiter and thyroid nodular disease in patients with class III obesity
}

\author{
Prevalência de bócio e doença nodular tireoidiana \\ em pacientes com obesidade grau III
}

Priscila Alves Medeiros de Sousa', Mario Vaisman', João Regis Ivar Carneiro², Lorena Guimarães' ${ }^{1}$, Heloisa Freitas', Maria Fernanda Castellar Pinheiro ${ }^{3}$, Sally Liechocki ${ }^{4}$, Clarissa Menezes Maya Monteiro ${ }^{4}$, Patrícia de Fátima dos Santos Teixeira ${ }^{1}$

1 Endocrinology Service, Medicine School, Universidade Federal do Rio de Janeiro, Hospital Universitário Clementino Fraga Filho (UFRJ/ HUCFF), Rio de Janeiro, RJ, Brazil ${ }^{2}$ Nutrology Service and Radiology Department, Medicine School, UFRJ/HUCFF, Rio de Janeiro, RJ, Brazil ${ }^{3}$ Sergio Franco Medicina Diagnóstica, Duque de Caxias, RJ, Brazil

${ }^{4}$ Fundação Oswaldo Cruz (Fiocruz), Laboratório de Imunofarmacologia, Rio de Janeiro, RJ, Brazil
Correspondence to: Priscila Alves Medeiros de Sousa alves_priscila@hotmail.com

Received on Jul/16/2012 Accepted on Sept/12/2012

\begin{abstract}
Objectives: To evaluate the prevalence of goiter and nodular disease in patients with class III obesity, and to correlate results with serum leptin levels and insulin resistance (IR) parameters. Subjects and methods: A cross-sectional study was performed to assess thyroid ultrasound (US) patterns, HOMA-IR, serum leptin, and TSH levels in obese patients and controls. Results: Thyroid volume was positively correlated with body mass index (BMI) $(r=0.240$, $p=0.039)$ and with HOMA-IR $(r=0.329 ; p<0.01)$. Thyroid US patterns were similar between groups. However, when data from the male group was considered, greater thyroid volume was detected in the obese group compared with controls (10.8 vs. $\left.8.5 \mathrm{~cm}^{3} ; p=0.04\right)$. Also, nodules were more frequently detected $(67 \%$ vs. $18 \%)$, as were nodules requiring FNAB (33.3\% vs. $0 \%, p \geq 0.05-0.09)$, in this group. Conclusion: Although IR did not correlate directly with the presence of nodules, the results support the hypothesis of a direct association between insulin resistance and thyroid volume. Arq Bras Endocrinol Metab. 2013;57(2):120-5
\end{abstract}

\section{Keywords}

Obesity; insulin resistance; goiter; thyroid nodule

\section{RESUMO}

Objetivos: Avaliar a prevalência de bócio e doença nodular tireoidiana em pacientes com obesidade grau III e correlacionar os resultados com os níveis de leptina e parâmetros de resistência à ação da insulina (RI). Sujeitos e métodos: Estudo seccional foi desenvolvido realizando ultrassonografia (US) tireoidiana e níveis séricos de HOMA-IR e TSH nos pacientes obesos e nos controles. Resultados: Volume tireoidiano foi positivamente correlacionado com índice de massa corporal (IMC) ( $r=0,240, p=0,039)$ e com HOMA ( $r=$ $0,329 ; p<0,01)$. Volume tireoidiano e prevalência de doença nodular tireoidiana foram similares entre os grupos. Quando avaliado o subgrupo masculino, maiores volumes tireoidianos foram detectados no grupo dos obesos comparados aos controles $(10,8 \mathrm{vs}$. 8,5 $\left.\mathrm{cm}^{3} ; \mathrm{p}=0,04\right)$, nódulos foram mais frequentes ( $67 \%$ vs. $18 \%$ ), assim como nódulos com indicação de punção $(33,3 \%$ vs. $0 \%, p \geq 0,05-0,09)$. Conclusão: Embora RI não se correlacione diretamente com a presença de nódulos, os resultados suportam a hipótese da direta associação entre resistência à ação da insulina e volume tireoidiano. Arq Bras Endocrinol Metab. 2013;57(2):120-5

\section{Descritores}

Obesidade; resistência à insulina; bócio; nódulo da glândula tireoide 


\section{INTRODUCTION}

$\mathrm{T}$ he significant increase in the worldwide prevalence of overweight and obese individuals is an important public health issue at the start of this century, both in developed and developing countries. Additionally, the prevalence of more severe forms of obesity, defined as class III obesity, has been increasing worldwide (1). Over recent years, various publications have focused on the association between insulin resistance (IR) and thyroid abnormalities (2-8). Causes of thyroid dysfunction are positively associated with IR, not only in subjects diagnosed with diabetes mellitus (DM), but also in subjects without this diagnosis (9).

Thyroid nodular disease and differentiated thyroid carcinoma have also been regarded as a possible new spectrum of IR (2). It has been suggested that subjects with hyperinsulinemia may present greater thyroid size and greater prevalence of nodules (2). This finding is in accordance with reported studies from patients with acromegaly, in which the prevalence of goiter and nodules was found to be greater, probably as a result of the increased activity of IGF-1 (10). Elevated prevalence of IR in patients with differentiated thyroid carcinoma has also been demonstrated (11).

The aim of this study was to describe thyroid ultrasound (US) findings of subjects with class III obesity. Another aim was to correlate thyroid volume and prevalence of thyroid nodules with BMI, IR evaluated by homeostatic model assessment (HOMA-IR), serum leptin and thyroid stimulating hormone (TSH) levels.

\section{SUBJECTS AND METHODS}

A cross-sectional study was conducted. Both the experimental group and the control group subjects were submitted to thyroid US and laboratory analyses to determine levels of serum TSH, free T4, anti-TPO, leptin, glucose, and insulin (for HOMA-IR calculation). The experimental group was composed of patients who were followed up in the bariatric surgery program at Clementino Fraga Filho Hospital (HUCFF), Rio de Janeiro, Brazil, before they underwent any bariatric surgical procedure. At the moment, the main indication for bariatric surgery at this hospital is body mass index $(\mathrm{BMI}) \geq 40 \mathrm{~kg} / \mathrm{m}^{2}$. The control group was selected from healthy volunteers with similar demographic characteristics regarding age and sex. Male and female patients were selected and matched between groups. In the experimental group, all individuals had class III obesity (BMI $\geq 40 \mathrm{~kg} / \mathrm{m}^{2}$ ), and all individuals in the control group had normal BMI levels $\left(<25 \mathrm{~kg} / \mathrm{m}^{2}\right)$. The exclusion criteria were diagnosis of DM type 2, use of medication that could interfere with insulin sensitivity, and known thyroid disease, and were the same for both groups. All research subjects signed an informed consent form, and the study was approved by the local ethics committee.

Participants in the study were submitted to specific anamnesis and a physical examination. They were weighed wearing light clothing and footwear in Filizo$1 a^{\circledR}$ scales. BMI was calculated by means of the following formula: $\mathrm{BMI}=$ weight $/$ height $^{2}$.

All ultrasound exams were performed by the same radiologist, using a high-frequency SIEMENSACUSON X300 multi-frequency transducer (12 $\mathrm{MHz}$ ). Thyroid volume was calculated by the formula: length $\mathrm{x}$ width $\mathrm{x}$ thickness $\mathrm{x} 0.52$ of each lobe and the isthmus (11). The characteristics of the thyroid parenchyma were described according to their echogenicity and homogeneity. Focal lesions were only considered present when their diameter exceeded $3.0 \mathrm{~mm}$. These lesions were classified as cysts and nodules, which could be mists or solid. Solid lesions with a diameter of 10 $\mathrm{mm}$ or greater, and smaller solid lesions with suspicious US pattern (hypoechogenicity with microcalcifications) were described as nodules, and required fine needle aspiration biopsy (FNAB).

Serum samples for laboratorial assays were obtained by venipuncture, after an 8 -hour fast.

Serum levels of TSH, FT4, and TPO-Ab were determined by immunochemiluminesce (Immulite, Diagnostic Products, Los Angeles, CA). Reference ranges for TSH and FT4 were $0.4-4.0 \mu \mathrm{UI} / \mathrm{mL}$ and 0.9-1.8 ng/dL, respectively. Serum levels of TPO$\mathrm{Ab}>35 \mathrm{UI} / \mathrm{mL}$ were considered positive. The intra-assay coefficients of variation were $3.8 \%-12.5 \%$, 4.4\%-7.5\% and $4.3 \%-5.6 \%$ for $\mathrm{TSH}_{2} \mathrm{FT}_{4}$ and $\mathrm{TPO}-$ $\mathrm{Ab}$, respectively, while inter-assay coefficients of variation were $4.6 \%-12.5 \%, 4.8 \%-9.0 \%$ and $7.8 \%-10.5 \%$, respectively.

Serum leptin was measured by a sandwich ELISA method (Human Leptin Duo Set Kit). Glucose was assayed by the colorimetric enzymatic method. The reference range for glucose was based on the guidelines of the American Diabetes Association (ADA) and the Brazilian Diabetes Society (SBD) $(12,13)$.

Serum insulin was measured by a Chemiluminescence Immunoassay Kit (COBAS/Device: Modular 
Analytics E 170, Roche) with a reference range of 2.0-23.0 $\mathrm{mcU} / \mathrm{mL}$, an intra-assay range of $0.7 \%-1.5 \%$ and an inter-assay range of $2.6 \%-4.9 \%$. HOMA-IR was calculated with the following formula: [Fasting blood glucose $(\mathrm{mmol} / \mathrm{L}) \times$ Fasting insulin $(\mathrm{mU} / \mathrm{L})] / 22.5$. Fasting blood glucose was then converted to $\mathrm{mmol} / \mathrm{L}$ by multiplying results in $\mathrm{mg} / \mathrm{dL}$ by 0.05551 .

Statistical analysis was performed with the SPSS software, version 13.0 for Windows. Continuous variables were expressed as means and standard deviations, and categorical variables were expressed as percentages. The Student's $t$-test or the Mann-Whitney test were used to compare two continuous variables according to the distribution of the variable in the studied sample, as assessed by the Kolmogorov-Smirnov test. Comparisons of the proportions between two groups were performed by the Chi-square test or Fisher's exact test. Correlation between two variables was assessed by Pearson's correlation coefficient ( $r$ ) after data were log-transformed. Partial correlation was used to detect the influence of confounding variables in specific correlations.

\section{RESULTS}

Between February 2010 and October 2011, thirty patients were admitted to the bariatric surgery program at Clementino Fraga Filho Hospital (HUCFF), Rio de Janeiro, Brazil. Nine patients were excluded (four were $>50$ years old, and five had DM), and 21 patients were included in the study. A control group of 40 healthy volunteers that was well-matched with the experimental group regarding gender and age, but with normal weight (IMC $<25 \mathrm{~kg} / \mathrm{m}^{2}$ ) was recruited. The demographic characteristics of the sample are presented in Table 1 .

Table 1. Demographic characteristics of obese subjects and the control group

\begin{tabular}{|c|c|c|}
\hline Variable & $\begin{array}{l}\text { Experimental group } \\
\qquad(\mathrm{n}=21)\end{array}$ & $\begin{array}{c}\text { Control group } \\
(n=40)\end{array}$ \\
\hline $\mathrm{BMI}\left(\mathrm{kg} / \mathrm{m}^{2}\right)^{\star}$ & $50.9 \pm 7.17(50)$ & $22.51 \pm 2.31(23)$ \\
\hline TSH $(\mu \mathrm{UI} / \mathrm{mL})$ & $2.92 \pm 2.26(2.2)$ & $2.27 \pm 1.69(1.8)$ \\
\hline FT4 (ng/dL) & $1.06 \pm 0.17(1.0)$ & $1.01 \pm 0.15(1.0)$ \\
\hline Leptin $(\mathrm{ng} / \mathrm{dL})^{*}$ & $\begin{array}{c}4,027.12 \pm 2,501.83 \\
(4,194.0)\end{array}$ & $487.8 \pm 82.4(762)$ \\
\hline HOMA-IR* & $5.6 \pm 3.98(5.6)$ & $1.4 \pm 1.10(1.1)$ \\
\hline Thyroid volume $\left(\mathrm{cm}^{3}\right)$ & $9.3 \pm 5.1(7.9)$ & $7.6 \pm 2.7(7.4)$ \\
\hline
\end{tabular}

${ }^{*} p<0.001$ in the comparison between the experimental and control group.
To assess the impact of gender in the results, a stratified analysis was performed after an exploratory analysis of baseline demographic data according to gender. These data are shown in table 2. Serum leptin and HOMA-IR were greater among obese subjects, independent of gender. Furthermore, thyroid volume was greater in male obese patients compared with control subjects.

Table 2. Demographic characteristics of obese and control subjects, according to gender

\begin{tabular}{|c|c|c|c|}
\hline & Control group & Experimental group & p-value \\
\hline \multicolumn{4}{|l|}{ Men } \\
\hline $\mathrm{TSH}(\mathrm{uUl} / \mathrm{mL})$ & $2.6 \pm 2.5(2.0)$ & $2.5 \pm 2.4(0.9)$ & NS \\
\hline $\mathrm{HOMA}^{*}$ & $1.2 \pm 0.8(0.7)$ & $8.7 \pm 5.7(4.0)$ & $<0.01$ \\
\hline $\begin{array}{l}\text { Thyroid } \\
\text { volume }\left(\mathrm{cm}^{3}\right)\end{array}$ & $9.2 \pm 1.7(8.5)$ & $15.7 \pm 9.6(10.8)$ & 0.04 \\
\hline Leptin* (ng/dL) & $373.0 \pm 2.0(343.0)$ & $5261.0 \pm 2.0(4700.0)$ & $<0.01$ \\
\hline \multicolumn{4}{|l|}{ Women } \\
\hline $\mathrm{TSH}(\mathrm{uUl} / \mathrm{mL})$ & $2.1 \pm 1.3(1.3)$ & $3.0 \pm 2.7(2.1)$ & NS \\
\hline $\mathrm{HOMA}^{*}$ & $1.1 \pm 1.1(0.7)$ & $4.3 \pm 2.2(2.7)$ & $<0.01$ \\
\hline $\begin{array}{l}\text { Thyroid } \\
\text { volume }\left(\mathrm{cm}^{3}\right)\end{array}$ & $7.0 \pm 2.8(6.8)$ & $7.6 \pm 2.2(7.5)$ & NS \\
\hline Leptin* (ng/dL) & $919.0 \pm 4.0(859.0)$ & $2796.0 \pm 2.0(2548.0)$ & $<0.01$ \\
\hline
\end{tabular}

Thyroid nodular disease was found in $35 \%$ of the patients of the experimental group and in $20 \%$ of the control group $(\mathrm{p}=0.171)$. There was a non-significant trend towards larger nodules, in average, in the experimental group $\left(1.4 \pm 1.4 \mathrm{~cm}^{3}\right.$ vs. $\left.0.9 \pm 0.5 \mathrm{~cm}^{3}\right)$.

The stratified analysis of gender revealed that $67 \%$ of obese men had abnormal US findings, in comparison with $28 \%$ in non-obese men (Table 3 ). Comparing males in the experimental group with those in control group, we found a relative risk of 3.67 for any kind of US abnormality (CI95\%:0.93-14.5, p = 0.05). In obese men, we found a prevalence of $33.3 \%$ of nodules that required $\mathrm{FNAB}$ in comparison with $0 \%$ in the control group. These comparisons showed borderline significant p-values. Greater prevalence of US abnormalities associated with obesity was not found in the female subgroup (Table 3 ).

HOMA-IR did not differ between subjects who required $\mathrm{FNAB}$ or not $(3.13 \pm 3.3$ vs. $2.6 \pm 3.0 ; \mathrm{p}=$ 0.696 ) and between those patients with normal $v s$. abnormal US findings $(2.8 \pm 2.4$ vs. $2.5 \pm 3.5 ; \mathrm{p}=0.765)$. However, HOMA-IR levels were greater, without statistical significance, in men who required FNAB (6.6 \pm 2.2 vs. $3.5 \pm 5.1 ; \mathrm{p}=0.136)$. For women, these values did not differ between obese or control individuals $(2.62 \pm 2.2 v s .1 .41 \pm 1.38 ; \mathrm{p}=0.481)$. 
Table 3. Prevalence of US abnormalities in obese and control subjects, according to gender

\begin{tabular}{lcc}
\hline Male & $\begin{array}{c}\text { Experimental } \\
\text { group (n= 6) }\end{array}$ & $\begin{array}{c}\text { Control group } \\
(\mathbf{n = 1 1 )}\end{array}$ \\
\hline Abnormal findings in US & $67 \%(4: 6)^{*}$ & $18 \%(2: 11)^{\star}$ \\
Nodules requiring FNAB ${ }^{* \star}$ & $33,3 \%(2: 6)^{\star}$ & $0 \%(0: 11)^{\star}$ \\
Nodular thyroid disease & $66.7 \%(4: 6)$ & $18.2 \%(2: 11)$ \\
\hline Female & $\begin{array}{c}\text { Experimental } \\
\text { group (n= 15) }\end{array}$ & $\begin{array}{c}\text { Control group } \\
(\mathbf{n}=\mathbf{2 9})\end{array}$ \\
\hline Abnormal findings in US & $47.5 \%(7: 15)$ & $28 \%(8: 29)$ \\
Nodules requiring FNAB & $6.7 \%(1: 15)$ & $10.3 \%(3: 29)$ \\
Nodular thyroid disease & $21.4 \%(3-15)^{\star}$ & $30.7 \%(6: 29)^{\star}$ \\
\hline
\end{tabular}

${ }^{*} \mathrm{p}$-values $\geq 0.05-0.09$; ** Solid lesions with a diameter of $10 \mathrm{~mm}$ or greater, and smaller solid lesions with a suspicious US pattern (hypoechogenicity with microcalcifications).

BMI and serum leptin were positively correlated $(\mathrm{r}=0.331, \mathrm{p}=0.016)$ and BMI correlated quite accurately with HOMA-IR $(\mathrm{r}=0.708, \mathrm{p}<0.001)$, as expected. BMI was also positively correlated with TSH serum levels $(\mathrm{r}=0.438, \mathrm{p}=0.023)$ in obese patients. Serum TSH did not correlate with HOMA-IR or serum leptin levels $(\mathrm{r}=$ $0.06, \mathrm{p}=0.325 ; \mathrm{r}=0.132, \mathrm{p}=0.190$, respectively).

Thyroid volumes did not correlate with serum TSH, but were positively correlated with BMI $(\mathrm{r}=0.240, \mathrm{p}=$ $0.039)$ and HOMA-IR $(\mathrm{r}=0.329, \mathrm{p}=0.007)$ in the entire group (Table 4 ). This latter association was stronger in the obese group $(\mathrm{r}=0.571, \mathrm{p}=0.01)$, but was still present among the controls $(\mathrm{r}=0.25 \mathrm{l}, \mathrm{p}=0.05)$. This correlation was independent from confounding parameters as detected in the partial correlation controlled for BMI $(r=0.230, p=0.04)$, leptin $(r=0.340, p=0.01)$ and TSH $(r=0.330, p=0.01)$. However, this was not an independent association, as it was absent when leptin and HOMA-IR were added as confounding variables. When the obese patient group was analyzed separately, leptin levels were positively correlated with thyroid volume $(r=0.771, p=0.036)$. Finally, we evaluated the prevalence of US findings in obese and control subjects according to gender stratified by HOMA-IR. We considered a predictor of an IR value of HOMA-IR > 2.5, and the results are shown in table 4 .

\section{DISCUSSION}

The results of this study demonstrate a positive correlation between thyroid volume and IR, as evaluated by HOMA-IR. Partial correlations, which considered TSH, BMI, and leptin as confounding factors, demonstrated that this correlation between thyroid volume and IR persisted, suggesting an independent correlation.
Table 4. Prevalence of US findings in obese and control subjects, according to gender, stratified by HOMA-IR

\begin{tabular}{lcc}
\hline & Male (n= 22) & Female (n= 38) \\
\hline Normal US & & \\
HOMA $<2.5$ & $68 \%(15 / 22)$ & $74 \%(28 / 38)$ \\
HOMA $>2.5$ & $32 \%(7 / 22)$ & $26 \%(10 / 38)$ \\
p. value & 0.29 & 0.46 \\
Nodule & & \\
HOMA $<2.5$ & $68 \%(15 / 22)$ & $74 \%(28 / 38)$ \\
HOMA $>2.5$ & $32 \%(7 / 22)$ & $26 \%(10 / 38)$ \\
p. value & 0.08 & 0.92 \\
Other changes & & \\
HOMA $<2.5$ & $68 \%(15 / 22)$ & $74 \%(28 / 38)$ \\
HOMA $>2.5$ & $32 \%(7 / 22)$ & $26 \%(10 / 38)$ \\
p. value & 0.16 & 0.28 \\
Greater extent & & \\
HOMA $<2.5$ & $1.100 \mathrm{~cm}^{3}$ & $0.980 \mathrm{~cm}^{3}$ \\
HOMA $>2.5$ & $1.550 \mathrm{~cm}^{3}$ & $0.500 \mathrm{~cm}^{3}$ \\
p. value & 0.21 & 0.81 \\
\hline
\end{tabular}

Increased insulin levels, which are consequence of IR, reduce the levels of IGF-1 binding proteins, thus raising free IGF-1 levels; IGF-1 can then bind to IGF-1 receptors, which are overexpressed in most cancer cells (14). IRS-1 is essential to the activation of cellular mitosis and its overexpression is linked to neoplastic transformation (15). Additionally, studies in acromegaly show that $64 \%-92 \%$ have thyroid changes in US $(10,16,17)$.

Various authors have previously suggested a link between IR and increased thyroid volume. Rezzónico and cols. were the first to describe the link between thyroid nodular disease and IR, and have reported that patients with differentiated thyroid carcinoma present an increase in IR parameters (2). However, IR could act by increasing thyroid proliferation regardless of the patient's BMI (3). The present study showed that IR was associated with thyroid volume, independent of BMI.

Another study showed that the average thyroid volume was significantly greater in patients with metabolic syndrome (MS) than in controls $(\mathrm{p}<0.001)$. Also, the percentage of patients with thyroid nodular disease was significantly higher in patients with MS $(\mathrm{p}<0.001)(4)$.

Although Mijović and cols. showed results different from those of the present study and of other previous studies, their study only considered individuals with thyroid nodules in which the FNAB had undetermined results, and who underwent a thyroidectomy. The 
characterization of this population lacked a description of serum TSH levels and nodule size, as well as any characterization of the goiter. Last, as this study was performed in a tertiary care reference center, thyroidectomy may have been performed as a result of other prognostic factors than just FNAB diagnosis. Obesity might play a role in the pre-operative evaluation (5).

Other studies have demonstrated an association between thyroid function and IR. Chiovatto and cols. concluded that metformin treatment decreases significantly serum TSH concentrations in patients with polycystic ovary syndrome (PCOS) and hypothyroidism, regardless of the concomitant thyroid replacement with levothyroxine therapy (6). The precise mechanisms of metformin action remain debated. The present study showed a positive and significant logarithmic correlation between thyroid volume and HOMA-IR, with TSH as a confounding factor $(\mathrm{p}=0.0 \mathrm{l})$. Recently, another study demonstrated the impact of metformin, either alone or combined with levothyroxine, in reducing the volume of hyperplasic thyroid nodules (7). Chiovatto and cols. also evaluated the accuracy of US in detecting autoimmune thyroid diseases in patients with class III obesity, and detected that class III obesity may affect thyroid morphology (8).

As there are differences in the prevalence of thyroid nodular disease between sexes and leptin levels may also differ, we performed a stratified evaluation according to gender. We detected that thyroid volume was significantly greater among obese men than in normal weight controls. Despite the absence of a higher prevalence of abnormal US findings in obese women, these results were more frequent among obese men in comparison with male controls, with borderline significance. The same occurred for the prevalence of nodules that required FNAB. Cappelli and cols. showed low prevalence of thyroid nodular disease in women with class III obesity (18). Therefore, among men, IR appears to play an important role in thyroid volume and in the development of thyroid nodular disease.

We did not find any independent correlation between TSH and thyroid volume. This was in accordance with previous reports that TSH alone is not a mitogenic factor (14).

Leptin, produced by the adipose tissue, is responsible for informing the central nervous system (CNS) of the energy reserves in adipose tissue. Various studies have been performed to understand the action of leptin on the thyroid axis. The main hypothesis is that leptin positively regulates TRH expression (19). In the experimental group, we found a strong positive correlation between thyroid volume and leptin, but such a correlation was lost in the control group. With a larger sample, it may be possible to document greater influence of leptin in thyroid nodular disease. Nevertheless, it is important to determine whether such association is independent of or related to IR.

These results strengthen the hypothesis of direct association between obesity and increased thyroid volumes, by means of IR. Further studies are necessary to confirm the association between leptin action and thyroid nodular disease. One of the limitations of the study is related to the limited number of patients, and to the sectional design, which interferes in the evidence of direct cause-consequence relationship between obesity, and/or insulin resistance, and goiter.

In conclusion, despite the similar prevalence of thyroid nodular disease between the obese and control groups of patients, there was a trend towards a higher frequency of the disease in obese male subjects. Although IR did not correlate directly with the presence of thyroid nodules, results also support the hypothesis of a direct association between insulin resistance and thyroid volume.

Acknowledgments: we are thankful for Patricia T. Bozza contributions and to Coordenação de Aperfeiçoamento de Pessoal de Nível Superior, Sistema Único de Saúde (Capes/SUS), Conselho Nacional de Desenvolvimento Científico e Tecnológico (CNPq), Fundação de Amparo à Pesquisa do Estado do Rio de Janeiro (Faperj), and Fundação Oswaldo Cruz (Fiocruz) support.

Disclosure: no potential conflict of interest relevant to this article was reported.

\section{REFERENCES}

1. Porto MCV, Brito IC, Calfa ADF, Amoras M, Villela NB, Araújo MB. Perfil do obeso classe III do ambulatório de um hospital universitário em Salvador, Bahia. Arq Bras Endocrinol Metabol. 2002;46:668-73.

2. Rezzónico JN, Rezzónico M, Pusiol E, Pitoia F, Niepomniszcze H. Increased prevalence of insulin resistance in patients with differentiated thyroid carcinoma. Metab Syndr Relat Disord. 2009; 7(4):375-80.

3. Rezzónico J, Rezzónico M, Pusiol E, Pitoia F, Niepomniszcze H. Introducing the thyroid gland as another victim of the insulin resistance syndrome. Thyroid. 2008;18(4):461-4.

4. Ayturk S, Gursoy A, Kut A, Anil C, Nar A, Tutuncu NB. Metabolic syndrome and its components are associated with increased thyroid volume and nodule prevalence in a mild-to-moderate iodinedeficient area. Eur J Endocrinol. 2009;161(4):599-605.

5. Mijović T, How J, Pakdaman M, Rochon L, Gologan O, Hier MP, et al. Body mass index in the evaluation of thyroid cancer risk. Thyroid. 2009;19:467-72. 
6. Rotondi M, Cappelli C, Magri F, Botta R, Dionisio R, lacobello C, et al. Thyroidal effect of metformin treatment in patients with polycystic ovary syndrome. Clin Endocrinol (Oxf). 2011;75(3):378-81.

7. Rezzónico J, Rezzónico M, Pusiol E, Pitoia F, Niepomniszcze H. Metformin treatment for small benign thyroid nodules in patients with insulin resistance. Metab Syndr Relat Disord. 2011;9:69-75.

8. Rotondi M, Cappelli C, Leporati P, Chytiris S, Zerbini F, Fonte R, et al. A hypoechoic pattern of the thyroid at ultrasound does not indicate autoimmune thyroid disease in patients with morbid obesity. Eur J Endocrinol. 2010;163(1):105-9.

9. Fernández-Real JM, López-Bermejo A, Castro A, Casamitjana $\mathrm{R}$, Ricart W. Thyroid function is intrinsically linked to insulin sensitivity and endothelium dependent vasodilation in healthy euthyroid subject. J Clin Endocrinol Metab. 2006;91:3337-43.

10. Miyakawa M, Saji M,Tsushima T, Wakai K, Shizume K. Thyroid volume and serum thyroglobulin levels in patients with acromegaly: correlation with plasma insulin like growth factor 1 levels. J Clin Endocrinol Metab. 1988;67:973-8.

11. Michalaki MA, Vagenakis AG, Leonardou AS, Argentou MN, Habeos IG, Makri MG, et al. Thyroid functions in humans with morbid obesity. Thyroid. 2006;16:73-8.

12. Position Statement: Standards of Medical Care in Diabetes 2012. Diabetes Care. 2012;5(Suppl. 1):S11-63.
13. Milech A, Angelucci AP, Golbert A, et al. Metodos e critérios para o diagnóstico de diabtes mellitus. In: Gomes MB, Lerario AC, editors. Diretrizes da Sociedade Brasileira de Diabetes 2009/Sociedade Brasileira de Diabetes. 3th ed. São Paulo: A. Araújo Silva Farmacêutica; 2009. p. 18-20.

14. Vella V, Sciacca L, Pandini G, Mineo R, Squatrito S, Vigneri R, et al.The IGF system in thyroid cancer: new concepts. Mol Path. 2001;54:121-4.

15. Brunn J, Block U, Ruf G, Bos I, Kunze WP, Scriba PC. Volumetric analysis of thyroid lobes by real time ultrasound. Dtsch Med Wochenschr. 1981;41:1338-40.

16. Cheung NW, Boyages SC. Increased incidence of neoplasias in females with acromegaly. Clin Endocrinol. 1997;47:323-7.

17. Ruchala M, Skiba A, Gurgul E, Uruski P, Wasko R, Sowinski J. The occurrence of thyroid focal lesions and a need for fine needle aspiration biopsy in patients with acromegaly due to an increased risk of thyroid cancer. Neuro Endocrinol Lett. 2009;30:382-6.

18. Cappelli C, Pirola I, Mittempergher F, De Martino E, Casella C, Agosti B, et al. Morbid obesity in women is associated to a lower prevalence of thyroid nodules. Obes Surg. 2012;22(3):460-4.

19. Zimmermann-Blesing T, Brabant G, Holst JJ, Feldt-Rasmussen $\mathrm{U}$. Circulation leptin and thyroid dysfunction. Eur J Endocrinol. 2003;149:257-71. 